\title{
A Study on Milking Practices Among Dairy Owners in A Rural Community of Singur Block, Hooghly District, West Bengal, India
}

\author{
Seru Lakshmi Vineesha*, Chendu Bharat Prasad M, Atul Raj, Sayan Bhattacharya, Amit Banik
}

All India Institute of Hygiene and Public Health, Kolkata, West Bengal, India

\section{*Corresponding Author}

Seru Lakshmi Vineesha

\section{Article History}

Received: 01.08.2019

Accepted: 27.08 .2019

Published: 30.09 .2019

\begin{abstract}
Majority of India's economy is based on Agriculture and it accounts for $18 \%$ of India's Gross Domestic Product (GDP). India is the largest milk producer and ranks second in milk production in the world. Even though India ranks first place in cattle and buffalo population, it stands second in milk production. One of the reasons for less milk production would be lack of knowledge and hygienic milking practices among the dairy owners and the milkmen. The objective of the study is to assess the extent of knowledge and practices on clean milk production among livestock owners and milkmen in Singur. Using sample size calculation formula, 100 respondents were interviewed with a pre tested questionnaire. The data were analyzed using simple statistical procedures. The study revealed that majority of the respondents $(70 \%)$ were of middle age (35-50yrs), having education qualification up to Secondary level (84\%). Among the respondents, $77 \%$ were small holder dairy farmers having herd size up to 3 cows. More than $60 \%$ follow stripping technique but practise complete milking of udder. None of the respondents followed the dry cow therapy and checked for abnormality in first strip of milk. A major proportion of the respondents $(88 \%)$ do not have knowledge on milk borne zoonoses which is alarming. In conclusion, it is recommended that awareness needs to be created among dairy farmers regarding clean milk production with emphasis on the risks associated with people not following hygienic practices.
\end{abstract}

Keywords: Milkmen, knowledge, clean milk, Dairy practices, Hygiene, Singur.

\section{INTRODUCTION}

Dairy production is essential for economic development and sustainable communities in rural areas [1]. India has emerged as the highest milk producing country in the world [2] with an annual production of more than 176.3 million tones (2017-2018). Majority of India's economy is based on Agriculture and it accounts for $18 \%$ of India's Gross Domestic Product (GDP). It provides employment to $50 \%$ of the countries workforce. India is the largest milk producer and ranks second in milk production in the world. $21.34 \%$ of the world's milk is produced in India. Even though India is the largest milk producer, the milk production per animal is less when compared to the cattle of western countries. A single pure bred Holstein friesian in America produces on an average of 30 litres of milk per day. India ranks first place in cattle and buffalo population but it stands second in milk production (7.15 litres/Cow/Day). With the introduction of General Agreement on Tariffs and Trade (GATT), marketing of milk to any foreign country has become a reality [3]. Milk is a highly perishable commodity. Contaminated milk deteriorates quickly and produces diseases if consumed.

Therefore extreme care has to be taken in production, storage and transport of milk. Small holder milk producers form majority of India's milk production system [4]. Clean milk does not mean making the milk free from extraneous matters by passing it through sieve or muslin cloth [5]. It actually means the raw milk that has been produced in the udder of healthy dairy animals, handled under hygienic conditions and contains only allowed quantity of pathogens and chemicals [6]. There are mainly four factors to be considered in Clean Milk Production (CMP) practices. The animals should be maintained in hygienic environment for production of quality milk. Milking hygiene covers management of personal hygiene of the milkman and milking process [7]. Milking should be done using the full hand technique [5]. Milking vessels must have smooth milk contact surfaces with minimal joints and crevices [5]. It includes management practices during collection and transportation of milk. The milk secreted into an uninfected cow's udder is sterile. Milk at the time of milking will be at the body temperature. Preserving the milk at that temperature causes deterioration quickly. As such the milk should be chilled and stored. Chilling of milk enhances the storage time without spoiling. While transporting milk to the dairies the cold chain should be maintained for preventing deterioration. The milk has to be cooled to a temperature below $50^{\circ} \mathrm{C}$

Copyright @ 2019: This is an open-access article distributed under the terms of the Creative Commons Attribution license which permits unrestricted use, distribution, and reproduction in any medium for non commercial use (NonCommercial, or CC-BY-NC) provided the original author and source are credited. 
by using refrigerators / water coolers preferably within 2 hours after milking. The milk can be cooled by immersing the cans of milk in clean, running water. In small communities the risk of milk borne zoonoses in humans remains threat as they apply their own set of hygiene rules in the milking process. One of the reasons for less milk production would be lack of knowledge and hygienic milking practices among the dairy owners and the milkmen. Hence an understanding of farmer's knowledge on hygiene milking practices and milk borne zoonoses is required.

\section{Materials AND Methods}

Place and period of study: Singur block of Hooghly district during December 2018 - January 2019.

A total of 100 livestock owners were selected randomly in and around Singur region. Multistage random sampling technique was used to select the respondents. Singur block was purposively selected for the study. From the selected block, a list of villages with maximum populations of milch animals was identified. Out of the list of identified villages, ten villages were randomly selected for the study. From each selected villages 10 farmers were selected randomly thus making a total of 100 farmers. Each farmer were interviewed with a questionnaire containing both open and close ended questions on various aspects of clean milk production. A total of 21 questions were framed to assess the knowledge, attitude and practices on clean milk production. The data was collected and results were analyzed using simple statistical methods.

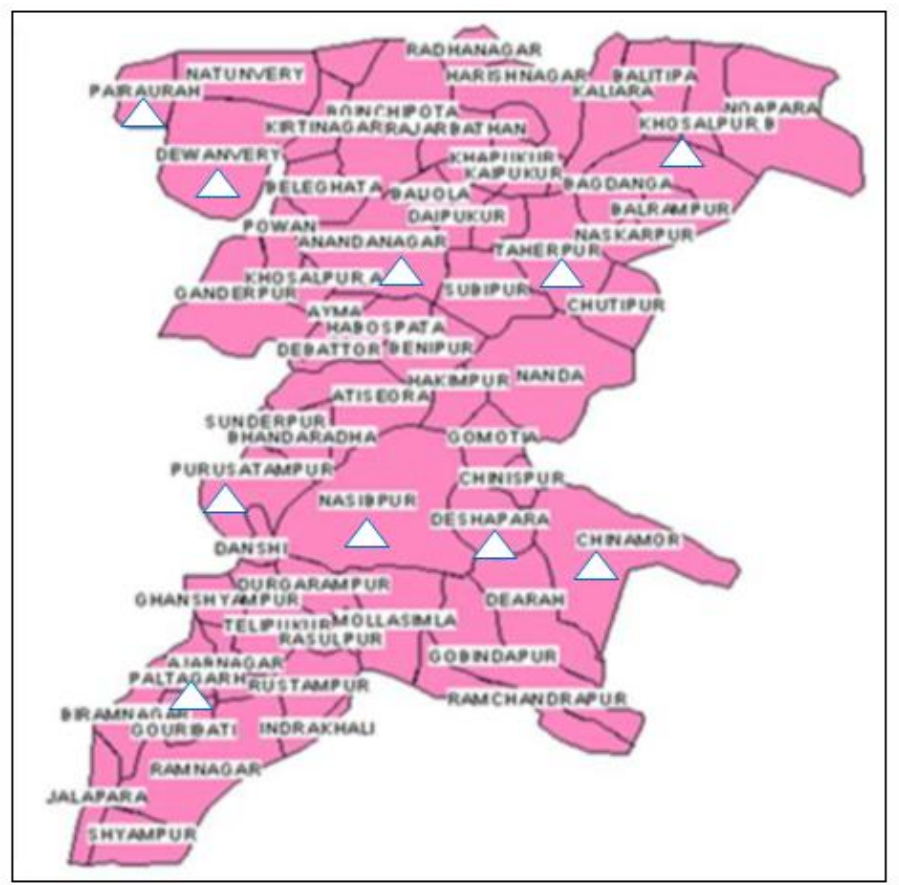

Map of Singur showing 64 revenue villages and sampling area of 10 villages represented by triangle

\section{RESULTS AND DISCUSSION}

Table-1: Socio-Demographic Characteristics

\begin{tabular}{|c|c|c|c|c|}
\hline S. No & Particulars & Range & Percentage (\%) & $\begin{array}{l}\text { Frequency } \\
(n=100)\end{array}$ \\
\hline \multirow[t]{3}{*}{1.} & \multirow[t]{3}{*}{ Age } & Young & $10 \%$ & 10 \\
\hline & & Middle & $70 \%$ & 70 \\
\hline & & Old & $20 \%$ & 20 \\
\hline \multirow[t]{3}{*}{2.} & \multirow[t]{3}{*}{ Education } & Illiterate & $31 \%$ & 31 \\
\hline & & Primary\&Secondary & $53 \%$ & 53 \\
\hline & & Higher Secondary\& Above & $16 \%$ & 16 \\
\hline \multirow[t]{2}{*}{3.} & \multirow[t]{2}{*}{ Monthly income } & $>5000$ & $61 \%$ & 61 \\
\hline & & $<5000$ & $39 \%$ & 39 \\
\hline \multirow[t]{2}{*}{4.} & \multirow[t]{2}{*}{ Herd size } & Up to 3 cows & $77 \%$ & 77 \\
\hline & & $>3$ cows & $23 \%$ & 23 \\
\hline \multirow[t]{2}{*}{5.} & \multirow[t]{2}{*}{ Daily average milk production } & Up to 5 litres & $66 \%$ & 66 \\
\hline & & Up to 10 litres \&above & $34 \%$ & 34 \\
\hline
\end{tabular}


Socio-demographic characteristics of dairy farmers are shown in Table-1.On analysing the profile of respondents, it was revealed that majority of the dairy farmers were in the middle aged group (70\%), having school education (84\%), and in the category of above Rs 5000 of monthly income (61\%). Most of them reared up to three dairy animals $(77 \%)$ and their daily average milk production of most of them was only up to 5 litres $(66 \%)$.

Table-2: Animal Hygiene

\begin{tabular}{|l|l|l|}
\hline S. No & Particulars & Percentage(\%)(n=100) \\
\hline 1. & Wash and clean animal everyday & $0 \%$ \\
\hline 2. & Wash udder for removal of mud and dung & $19 \%$ \\
\hline 3. & Clip hairs around the udder and hind quarters & $0 \%$ \\
\hline 4. & Teat dipping & $1 \%$ \\
\hline 5. & Full hand milking & $15 \%$ \\
\hline 6. & Vaccinate milking animal regularly & $67 \%$ \\
\hline
\end{tabular}

Table-2 shows the animal hygiene measures followed by the farmers. Not a single respondent practiced washing entire animal or washing hind quarter or back of cows before milking. Only $19 \%$ of respondents practiced cleaning udder and teats of cows before milking. Only $1 \%$ of respondents practice pre-milking teat dipping in potassium permanganate solution. Very few of the respondents (15\%) were practicing full hand milking. About $67 \%$ of the respondents vaccinate their milking animals regularly.

Table-3: Milk Hygiene

\begin{tabular}{|l|l|l|}
\hline S. No & Particulars & Percentage (\%)(n=100) \\
\hline 1. & Washing of hands before milking & $39 \%$ \\
\hline 2. & Use of clean, dry \&hygienic utensils & $83 \%$ \\
\hline 3. & Before starting milking drop out few strips of milk & $3 \%$ \\
\hline 4. & Passing of milk through sieve or muslin cloth & $4 \%$ \\
\hline 5. & Adding water in milk & $45 \%$ \\
\hline 6. & Use of separate utensils for healthy and sick animals & $5 \%$ \\
\hline 7. & Always stop milk handling while showing disease symptoms & $13 \%$ \\
\hline
\end{tabular}

Table- 3 shows milk hygiene measures followed by the respondents. Among the respondents $39 \%$ wash their hands with plain water before milking. Majority (83\%) of respondents followed the practices of using clean, dry and hygienic utensil for milking purpose. Only $3 \%$ of the dairy farmers responded correctly for checking the first strip of milk for any abnormality. Very few respondents had adopted the practice of passing the milk from a sieve or muslin cloth for removal of dirt. About $45 \%$ of respondents adulterate milk with water to increase the quantity. Very few (5\%) of respondents use separate utensil for milking of healthy and sick animals. Milking by healthy person is adopted by only $13 \%$ of respondents.

Table-4: Environmental Hygiene

\begin{tabular}{|l|l|l|}
\hline S. No & Particulars & $\begin{array}{l}\text { Percentage (\%) } \\
(\mathbf{n = 1 0 0 )}\end{array}$ \\
\hline 1. & Provide ventilation to animal house & $27 \%$ \\
\hline 2. & Drainage system in shed & $32 \%$ \\
\hline 3. & Washing of floor & $39 \%$ \\
\hline 4. & Separate area for milking & $20 \%$ \\
\hline 5. & Keeping milking area clean & $9 \%$ \\
\hline
\end{tabular}

Hygiene of animal house is an important component of clean milk production practices. Only $27 \%$ of respondents provide ventilation to animal house. Very few $(32 \%)$ of respondents have constructed pucca floor and well drainage system in animal shed.

\section{Post-Milking Practices}

Due to lack of cold storage facility, none of them follow cooling of milk to increase the keeping quality. This indicates that there are chances of spoilage of milk. Majority of respondents (98\%) prepare chenna with spoiled milk.

Only $9 \%$ and $12 \%$ respondents have knowledge on zoonoses and milk borne infections. Majority of the respondents believe that consumption of milk causes digestive disturbances. 


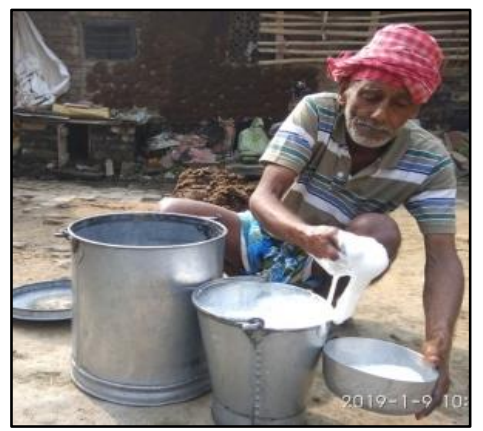

Fig-1: Unhygienic handling of milk

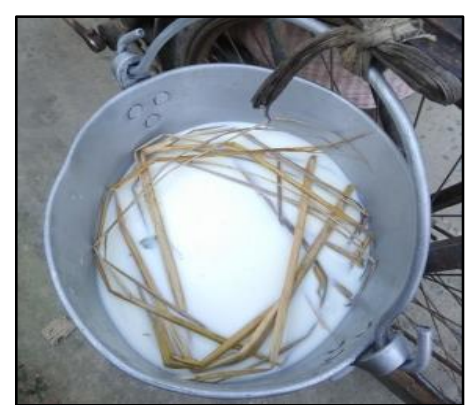

Fig-2: Contaminated milk
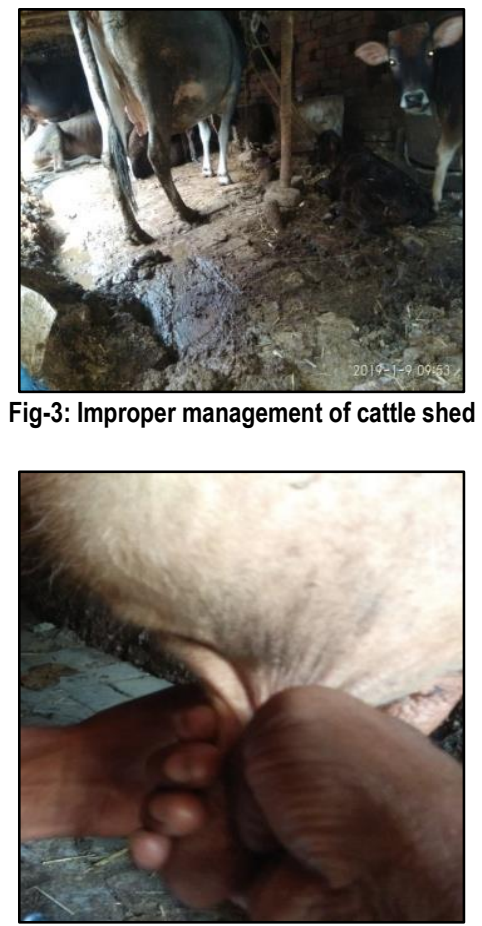

Fig-4: Knuckling

\section{CONCLUSION}

Dairy farmers' cattle and milk borne zoonoses awareness was found to be low. It is imperative to provide training to dairy farmers to increase their awareness on milk hygiene, cattle, milk borne zoonoses and their control methods in order to reduce public health risks.

\section{ACKNOWLEDGEMENTS}

The authors thank Rural Health Centre and Training Institute, Singur, Department of Microbiology and Department of Epidemiology, All India Institute of Hygiene and Public Health for providing necessary help to conduct this study. 
The authors also Thank Prof. Raj Kumar, Rajiv Gandhi Institute of Veterinary Education and Research, Puducherry for giving his valuable support to conduct the research.

\section{REFERENCES}

1. Douphrate, D. I., Hagevoort, G. R., Nonnenmann, M. W., Lunner Kolstrup, C., Reynolds, S. J., Jakob, M., \& Kinsel, M. (2013). The dairy industry: a brief description of production practices, trends, and farm characteristics around the world. Journal of agromedicine, 18(3), 187-197.

2. Sherikar, A. T., Bachhil, V. N., Thaliyal, D. C. Text book on Elements of veterinary Public Health.

3. Bafanda, R. A., Nanda, R., Choudhary, F., Choudhary, M. S., \& Shehjar, F. (2018). Clean Milk Production Practices Adopted by the Dairy Farmers of RS Pura in Jammu District. Asian Journal of Agricultural Extension, Economics \& Sociology, 1-10.

4. Package of practices for clean milk production. Available from: https://kk.icar.gov.in

5. Jacob, S. K., \& George, A. (2013). Analysis of the clean milk production practices of dairy farmers of Kerala. Indian journal of applied research, 3(7), 604-606.

6. Kevineotieno, Key Clean Milk Production Principles You Must Implement for quality dairy production. Accessed on 3. July 2017, Available from: (www.dairytechnologist.com) 